\title{
ANÁLISE DA ADEQUAÇÃO AMBIENTAL E MANEJO DOS DEJETOS DE INSTALAÇÕES PARA SUINOCULTURA EM PROPRIEDADES NA REGIÃO OESTE DO PARANÁ
}

\author{
JACIR DAGA ${ }^{1}$, ALESSANDRO T. CAMPOS ${ }^{2}$, ARMIN FEIDEN $^{3}$, \\ ELCIO S. KLOSOWSKI ${ }^{3}$, ROBERTO J. CÂMARA ${ }^{4}$
}

\begin{abstract}
RESUMO: Os dejetos de suínos são resíduos altamente poluidores, que prejudicam o meio ambiente, em especial a qualidade da água e o desenvolvimento de peixes e outros organismos aquáticos. Com isso, o objetivo deste trabalho foi verificar o perfil da suinocultura, a análise da adequação das instalações, os sistemas de manejo dos dejetos, bem como a adequação à legislação ambiental das propriedades agrícolas localizadas na microbacia do Córrego Ajuricaba, selecionada e localizada na bacia hidrográfica do Rio São Francisco Verdadeiro, na região Oeste do Paraná. Os resultados apresentados neste trabalho referem-se a dez propriedades das 110 analisadas. O perfil da suinocultura é de $80 \%$ dos suinocultores com sistema de criação em terminação e $20 \%$ em ciclo completo; nenhuma das instalações possui o sistema de lâmina d'água; todas as instalações utilizam o sistema de limpeza por raspagem; a freqüência de limpeza das baias nas instalações é diária e, em $90 \%$ das instalações, não foi observado desperdício de ração. O principal problema detectado nas construções foi o acesso das águas da chuva nas canaletas. No aspecto da legislação ambiental, constatou-se que todas as propriedades da microbacia analisada possuem problemas com a mata ciliar.
\end{abstract}

PALAVRAS-CHAVE: resíduos, sustentabilidade, construções para suínos.

\section{ANALYSIS OF THE ENVIRONMENTAL ADEQUACY AND MANAGEMENT OF DEJECTIONS ON SWINE BUILDINGS IN FARMS IN THE WEST REGION OF THE STATE OF PARANÁ, SOUTHERN BRAZIL}

\begin{abstract}
The swine dejections are polluting residues that harm the environment, in special the water quality and the development of fish and other aquatic organisms. The objective of this work was to verify the profile of the swine raise, analysis of the adequacy of the installations, the systems of the dejection handling, as well as the adequacy to the environmental legislation of the agricultural properties located in the microatchment of Ajuricaba stream, selected and located in the hydrographical basin of the São Francisco Verdadeiro River, in the western region of Paraná. The results presented in this work mention ten properties of 110 analyzed. The profile of the swine raise is of $80 \%$ of the swine breeder with handling system in termination and $20 \%$ in complete cycle; none of the buildings have the thin layer water system; all the installations uses the system of scraping cleanness; the frequency of the cleanness of the bay in the installations is daily; wastefulness of ration in $90 \%$ of the evaluated installations was not observed; the main problem of the installations is the access of rain water in the narrow channels and all the properties of the microatchment of the Ajuricaba stream have problems with the clear forest.
\end{abstract}

KEYWORDS: residues, sustainability, swine structures.

\footnotetext{
${ }^{1}$ Eng ${ }^{o}$ Agrônomo, Mestre em Agronomia, ex-bolsista da Capes - PPGAM/CCA/GPEA/Unioeste, Marechal Cândido Rondon, Rua Pernambuco, 1777, fone/fax (0XX45) 3254.3216, jacirdaga@ yahoo.com.br

${ }^{2}$ Prof. Dr., Instituto de Ciências Agrárias, UFVJM, Diamantina - MG, Fone: (0XX38) 3531.1811, atcampos3@yahoo.com.br

${ }^{3}$ Prof. Adjunto, CCA/Unioeste, Marechal Cândido Rondon - PR

${ }^{4}$ Mestre em Agronomia - CCA/Unioeste, Marechal Cândido Rondon - PR.

Recebido pelo Conselho Editorial em: 24-11-2005
}

Aprovado pelo Conselho Editorial em: 30-3-2007 


\section{INTRODUÇÃO}

O Brasil possui plantel de 34,5 milhões de cabeças de suínos, semelhante a 2003. Estima-se que 733 mil pessoas dependam diretamente da cadeia produtiva da suinocultura brasileira, que é responsável pela renda de 2,7 milhões de brasileiros. O valor da cadeia produtiva da suinocultura é estimado em US\$ 1,56 bilhão. Em 1970, o plantel era de 31,5 milhões de cabeças, com produção de 705 mil toneladas. Em 2003, com 34,5 milhões de cabeças, a produção aumentou para 2,696 milhões de toneladas. Portanto, em 33 anos, o crescimento do plantel foi de apenas 9,6\% enquanto a produção aumentou $261 \%$. Esses números exemplificam a evolução tecnológica do setor nesse período, graças ao forte trabalho dos técnicos e criadores nas áreas de genética, nutrição e manejo (IBGE, 2003).

Segundo BLEY JÚNIOR (2003), a tendência da suinocultura no Brasil é crescer. Estima-se que o rebanho triplique das 34 milhões de cabeças, durante esta próxima década.

É sabido que dejetos de suínos são resíduos altamente poluidores, que prejudicam o meio ambiente, em especial a qualidade da água e o desenvolvimento de peixes e outros organismos aquáticos. Os dejetos de suínos são 100 vezes mais poluentes que o esgoto urbano e representam grande problema ambiental, por serem altamente poluidores, no Brasil e na Europa (KONZEN, 1980; DOURMAD et al., 1999; VAN DER PEET-SCHWERING et al., 1999). OLIVEIRA (2005) complementa que cada matriz, em uma granja de ciclo completo, produz até $25 \mathrm{~m}^{3}$ de dejeções ao ano, que se compõem de esterco, urina, desperdícios de água de bebedouros ou de limpeza, resíduos de rações, etc.

A composição dos dejetos está associada ao sistema de manejo adotado, podendo apresentar grandes variações na concentração de seus componentes, dependendo da diluição e do modo como são manuseados e armazenados. A urina influi significativamente na quantidade de liquame que, por sua vez, depende diretamente da ingestão de água. Em geral, cada litro de água ingerido por um suíno resulta em 0,6 L de dejetos líquidos (OLIVEIRA, 1994).

O total de dejetos produzidos varia de acordo com o desenvolvimento corporal dos suínos, apresentando valores decrescentes de 8,5 a $4,9 \%$ de seu peso vivo dia ${ }^{-1}$, considerando a faixa dos 15 aos $100 \mathrm{~kg}$ de peso vivo (JELINEK, 1977).

A fermentação da matéria orgânica contida nos dejetos de suínos resulta na produção de odores, que são fonte de poluição ambiental e podem ser um entrave para a intensificação da suinocultura (MACKIE et al., 1998).

O fósforo, analogamente ao nitrogênio, é um nutriente muito importante para o crescimento e a reprodução de microrganismos que promovem a estabilização da matéria orgânica, porém o efluente rico em fósforo pode provocar proliferação excessiva de algas no curso d'água receptor (SILVA et al., 2003). SHARPLEY et al. (2000) complementam que o excesso de fósforo na água acelera a eutrofização, que é a principal causa de deteriorização da qualidade da água.

O consumo médio de 5,5 L de água suíno ${ }^{-1}$ dia $^{-1}$ foi encontrado por MAMEDE (1980), considerando suínos com peso na faixa de 36 a $97 \mathrm{~kg}$ e o método adotado de higienização das instalações e dos animais.

A literatura mundial relata inúmeros processos de tratamentos e/ou aproveitamento de resíduos orgânicos, destacando os processos biológicos, sejam os aeróbios (lodo ativado, lagoas de estabilização aeróbia, etc.), sejam os anaeróbios (biodigestores, lagoas de estabilização anaeróbia, etc.) para o tratamento de efluentes (FERNANDES JÚNIOR, 2001).

Visando à sustentabilidade dos sistemas de produção animal, os pesquisadores necessitam adequar as formas de manejo de modo que sejam compatíveis com a legislação ambiental (VAVRA, 1996).

O licenciamento ambiental para a suinocultura tem exigências prévias para a operação da atividade, as quais, no Paraná, são determinadas pela Resolução IAP/SEMA nº. 031/1998 (IAP, 1998). Segundo o sistema e o porte da atividade suinícola, podem ser exigidas licenças prévias, de instalação e de operação. De acordo com a Resolução citada, a complexidade das exigências 
aumenta com o porte da criação. Isso envolve desde o volume de dejetos produzidos pela atividade, tamanho e adequação das instalações, a distância das instalações e do sistema de armazenamento e/ou tratamento de dejetos em relação às nascentes de água, divisas da propriedade, estradas externas à propriedade, localização de rios ou drenagem natural mais próxima, número de instalações e características das instalações.

A legislação do Paraná prevê, desde 1982, que toda atividade suinícola esteja apta a realizar o correto manejo de seus dejetos e, em 1996, foi determinado o prazo limite até o ano de 2015 para regularização das granjas junto ao COPAM (Conselho de Política Ambiental), tornando obrigatório o registro junto a esse órgão, para que possa exercer livremente a atividade (OLIVEIRA, 2005).

Apesar dos esforços dos pesquisadores em divulgar e conscientizar os produtores, nota-se pouca iniciativa por parte desses para adequar suas instalações visando à sustentabilidade ambiental da atividade. $\mathrm{O}$ estudo de casos in loco, mediante contato direto com suinocultores e produtores, diagnosticando problemas e falhas nas instalações e propondo soluções factíveis e economicamente viáveis, constitui uma forma interessante de disseminar conhecimento no meio, além de possibilitar real noção do nível de contaminação das bacias, como subsídio para futuras políticas de adequação.

O objetivo deste trabalho foi verificar o perfil da suinocultura, análise da adequação das instalações, os sistemas de manejo dos dejetos, bem como a adequação à legislação ambiental de algumas propriedades da bacia hidrográfica do Rio São Francisco Verdadeiro, no município de Marechal Cândido Rondon - PR.

\section{MATERIAL E MÉTODOS}

O trabalho foi desenvolvido mediante convênio entre Itaipu Binacional (projeto Cultivando Água Boa) e a Unioeste, Universidade Estadual do Oeste do Paraná, através do Centro de Ciências Agrárias, Câmpus de Marechal Cândido Rondon - PR.

O estudo foi realizado na microbacia hidrográfica do Córrego Ajuricaba, localizada a sudoeste do centro urbano de Marechal Cândido Rondon (Figura 1), entre as coordenadas UTM

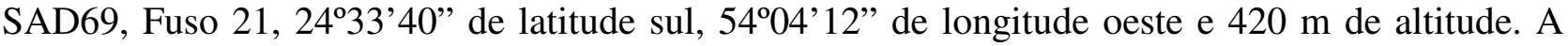
mesma possui área de 1.900 hectares, distribuídos em 110 lotes, caracterizada por pequenas propriedades, sendo $78 \%$ menores que 25 hectares, empregando, basicamente, mão-de-obra familiar.

Foram elaborados projetos de adequação ambiental em propriedades agrícolas localizadas na microbacia do Córrego Ajuricaba, pertencente à bacia hidrográfica do Rio São Francisco Verdadeiro, na região oeste do Paraná.

Os passivos ambientais, levantados e considerados neste trabalho, foram referentes à mata ciliar, reserva legal e suinocultura. Para essas propriedades, foram elaboradas propostas de readequação da atividade suinícola, por meio de projetos que seguem todas as exigências da legislação ambiental.

O trabalho foi realizado em duas etapas. Inicialmente, diagnosticaram-se as propriedades, levantando dados contendo informações cadastrais de cada produtor, da propriedade, número de instalações, área total, área agrícola, informações sobre o solo, relativos ao grau de risco ambiental e classe de risco ambiental, visando à aplicação de dejetos, uso atual das terras, visando a determinar o atendimento das exigências de mata ciliar e reserva legal.

Analisou-se o sistema hidráulico, sistema de canalização de água, de alimentação (comedouros), de drenagem e de armazenamento de dejetos (esterqueiras e canaletas de transporte). Com os dados levantados em cada propriedade, por meio de georreferenciamento com o auxílio de GPS, elaboraram-se mapas detalhados com auxílio de "Software" CAD (Desenho Auxiliado por Computador). Foram registradas, ainda, informações relativas à área de preservação permanente (mata ciliar), reserva legal, localização de nascentes, córregos e/ou rios, açudes, localização de estradas, divisas e instalações dentro das propriedades. 


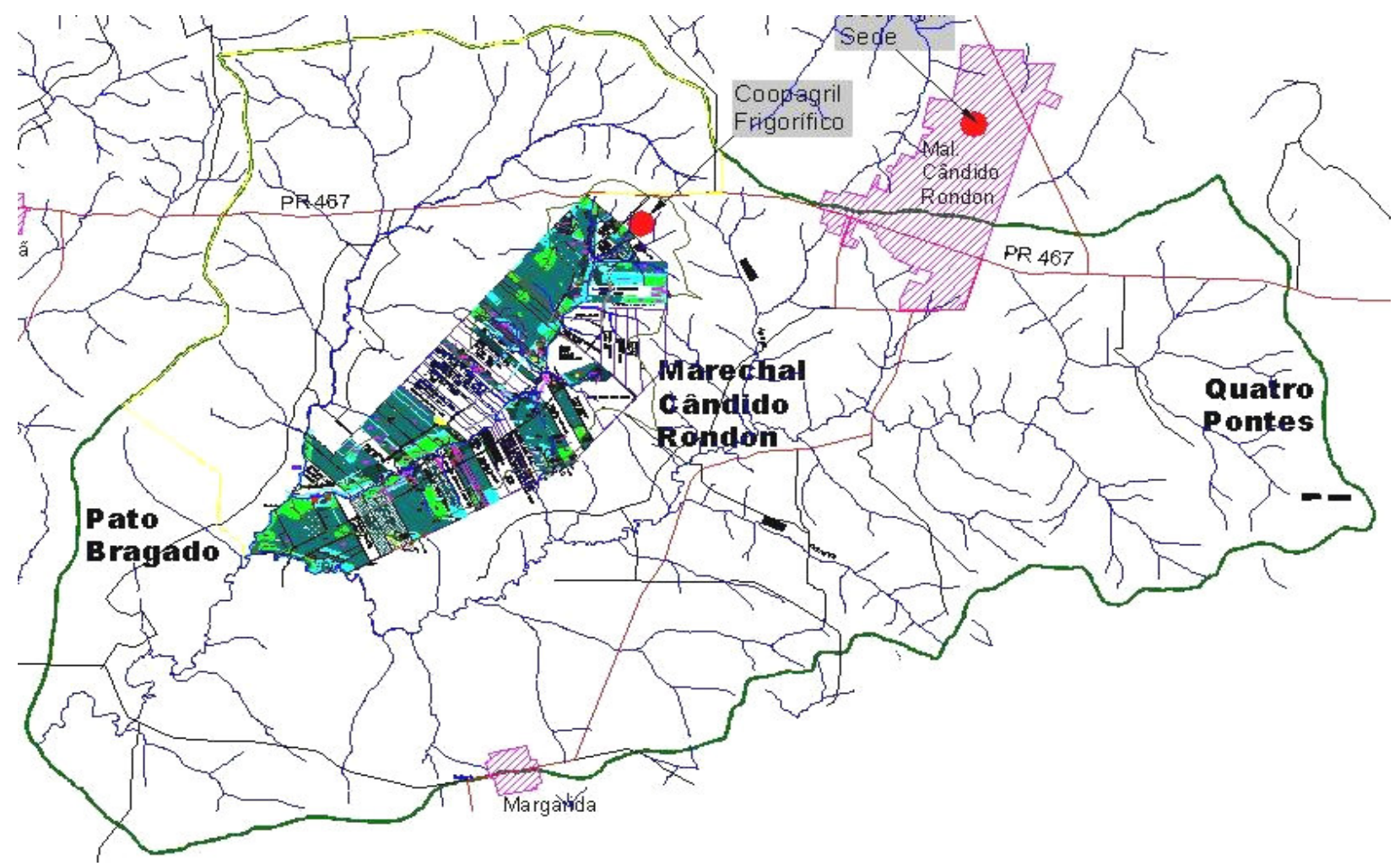

FIGURA 1. Localização da microbacia do Córrego Ajuricaba em relação ao município de Marechal Cândido Rondon - PR.

Das 110 propriedades pertencentes à microbacia do Córrego Ajuricaba, selecionaram-se, para este trabalho, as propriedades onde se verificou a ocorrência de suinocultura intensiva (as dez propriedades apresentadas na Figura 2).

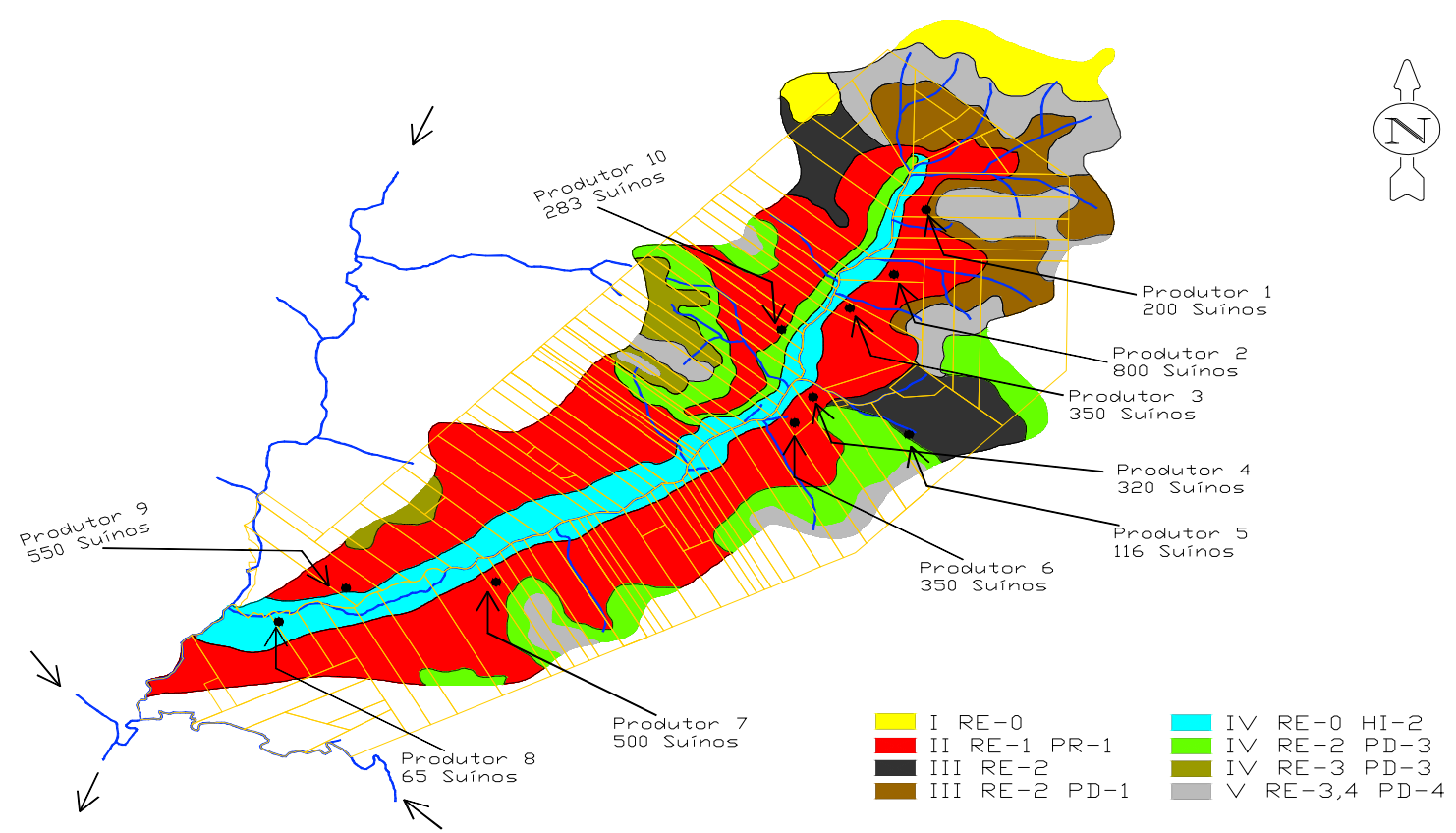

FIGURA 2. Imagem da classificação de terra e localização das suinoculturas da microbacia do Córrego Ajuricaba.

Posteriormente, produziram-se mapas com as readequações propostas, constando área com mata ciliar e reserva legal a serem implantadas, realocação das instalações que se encontravam nas áreas de preservação ambiental (matas ciliares e reservas legais) para outras áreas da propriedade ou, no caso de não apresentar alternativas locacionais, para outra propriedade do mesmo produtor, 
sendo em quaisquer dos casos observada a capacidade de suporte e as características ambientais e legais pertinentes, observando-se que as novas instalações deverão ser projetadas segundo critérios de funcionalidade e segurança ambiental e de eficiência zootécnica.

\section{RESULTADOS E DISCUSSÃO}

Analisando o perfil da suinocultura instalada na microbacia do Córrego Ajuricaba, no município de Marechal Cândido Rondon - PR, observa-se, pela Tabela 1, que $80 \%$ possui sistema de criação tipo terminação, em que $12,5 \%$ desses são de porte mínimo, $62,5 \%$ pequeno e $25,0 \%$ médio; sendo $20 \%$ do sistema de criação tipo ciclo completo, em que $100 \%$ desses são de porte mínimo, segundo classifica BLEY JUNIOR (2003), que considera o porte para terminação mínimo até 200 animais; pequeno de 201 a 500; médio de 501 a 1.500; grande de 1.501 a 4.000, e excepcional acima de 4.000 animais em terminação. O porte para ciclo completo é mínimo com até 20 matrizes; pequeno de 21 a 50; médio de 51 a 150; grande de 151 a 400, e excepcional acima de 400 matrizes.

TABELA 1. Proporção entre instalações de suinocultura para terminação e ciclo completo.

\begin{tabular}{cc}
\hline Sistema de Criação & Percentagem (\%) \\
\hline Terminação & 80 \\
Ciclo completo & 20 \\
\hline
\end{tabular}

Observa-se, na Tabela 2, que, das suinoculturas avaliadas, $78 \%$ estão integradas a empresas da região e $22 \%$ sem integração, ou seja, são autônomas.

TABELA 2. Proporção entre suinoculturas integradas à empresa da região e autônomas.

\begin{tabular}{cc}
\hline Suinoculturas & Percentagem (\%) \\
\hline Integradas & 78 \\
Autônomas & 22 \\
\hline
\end{tabular}

Analisando-se o sistema de limpeza das construções (Tabela 3), foi observado que, em 80\% das instalações, a limpeza é realizada somente por meio de raspagem, que é recomendado pelo IAP (1998), com o objetivo de evitar o consumo excessivo de água, com conseqüente elevação da diluição dos dejetos. Os demais usam raspagem e complementam a limpeza com sistema de lavagem.

TABELA 3. Manejo das instalações de suinocultura em relação à limpeza.

\begin{tabular}{llc}
\hline \multirow{2}{*}{ Tipo de limpeza } & Raspagem & $80 \%$ \\
\cline { 2 - 3 } & Raspagem + lavagem & $20 \%$ \\
\hline \multirow{2}{*}{ Freqüência de limpeza } & Diária & $80 \%$ \\
\cline { 2 - 3 } & Mais que um dia & $20 \%$ \\
\hline \multicolumn{2}{l}{ Desperdício de ração } & $0 \%$ \\
\hline \multicolumn{2}{l}{ Consumo de água por lavagem $\left(\right.$ dia $^{-1}$ instalação $\left.^{-1}\right)$} & 1.500 litros \\
\hline
\end{tabular}

Quando se utiliza limpeza por raspagem, a frequiência de limpeza diária ocorre em $80 \%$ das propriedades e $20 \%$ realizam a limpeza a cada dois dias ou mais, sendo a recomendação da Resolução IAP/SEMA n 031/1998 (IAP, 1998) que a limpeza seja diária.

Ao se proceder a um ensaio de pequeno porte em sistema de terminação pertencente ao projeto, observou-se que a limpeza com sistema de lavagem apresentou gasto de 1.500 litros de água, em média, por lavagem por dia, correspondendo à média de 4,3 litros de água suíno ${ }^{-1}$ dia $^{-1}$. BLEY JÚNIOR (2003) corrobora que, na IN (instrução normativa) IAP 105.006, considera-se que as perdas de água determinadas por deficiências nos sistemas hidráulicos, a água empregada no manejo e desperdícios também podem gerar aumento de volume de dejetos e, por isso, devem ser controladas. 
A alimentação dos suínos, em todas as instalações, é feita pelo menos três vezes ao dia, para evitar o desperdício de ração. Com isso, não foram observadas $10 \%$ das instalações com desperdício nos cochos, proporcionando a mistura da ração com os dejetos e o aumento da contaminação.

Na Figura 3, apresentam-se os resultados dos dados levantados relativos a aspectos das instalações, com percentual de todas as propriedades analisadas. Observou-se que, em 10\% das propriedades analisadas, as estruturas de alimentação necessitam de grandes modificações, pois fornecem o alimento no chão da baia, ocorrendo desperdício de ração, ou seja, não existem comedouros. Em 90\%, pode-se afirmar que estão adequadas, possuindo comedouros, não apresentando desperdícios expressivos de ração.

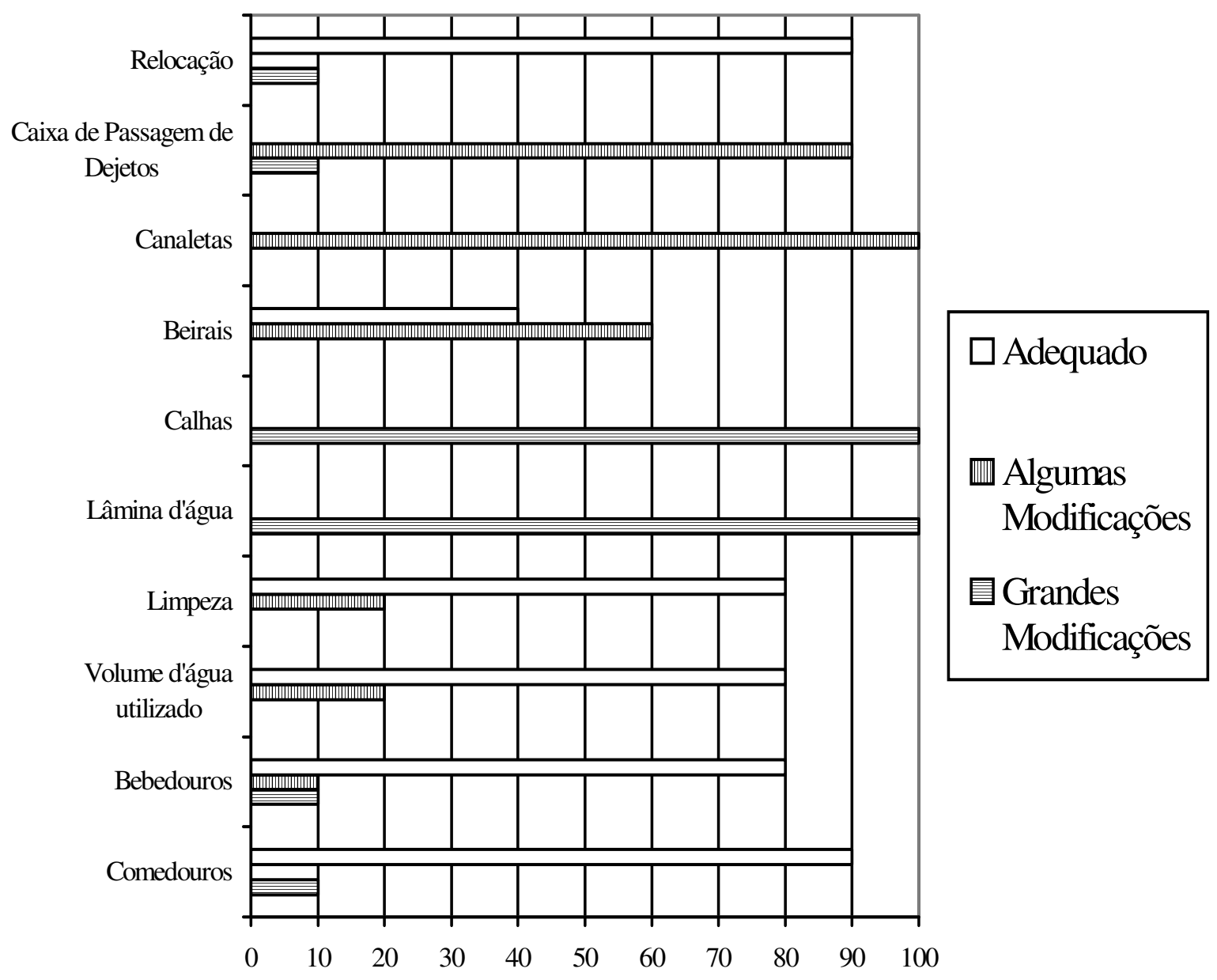

Percentagem $(\%)$

FIGURA 3. Análise das instalações de suinocultura, na microbacia do Córrego Ajuricaba, no município de Marechal Cândido Rondon - PR.

Em relação aos bebedouros, $10 \%$ das instalações requerem grandes modificações, pois estão com os bebedouros muito velhos e com vazamentos, evidenciando a necessidade de reposição; $10 \%$ precisam de algumas modificações, e $80 \%$ são adequados, sem vazamentos. O tipo de bebedouro mais encontrado foi o "nipple", seguido pelo de chupeta e concha, com percentuais de $55 \%, 30 \%$ e 15\%, respectivamente. OLIVEIRA (2002) conjectura que bebedouros ideais são aqueles que fornecem adequado volume de água por unidade de tempo, com baixa velocidade de escoamento, e inadequados são aqueles que geram volumes de água excedentes, não aproveitadas pelos animais. BLEY JÚNIOR (2003) complementa que os tipos mais comuns nas propriedades ainda são chupetas, normalmente fixas, sem dispositivos de ajuste de altura para adequá-las ao tamanho dos animais. Recomenda-se o emprego de bebedouros poupadores de desperdícios entre os que existem no mercado nacional. 
No volume d'água utilizado, $20 \%$ das propriedades necessitam de algumas modificações, pois fazem a limpeza com água, diluindo e aumentando o volume dos dejetos, e $80 \%$ estão adequados, como afirmado anteriormente.

Na limpeza das baias, $20 \%$ das instalações precisam de algumas modificações, uma vez que não fazem a limpeza das baias diariamente, e $80 \%$ estão adequadas, fazendo a limpeza diária por meio da raspagem e/ou vassoura, como determina a Resolução IAP/SEMA nº 031/1998 (IAP, 1998).

Analisaram-se as propriedades quanto à percentagem de instalações com lâmina d'água e observou-se que nenhuma das propriedades avaliadas possuía sistema de lâmina d'água (Figura 3). Segundo MOREIRA et al. (2003), a criação de suínos na fase de crescimento-terminação, em baias de lâmina d'água ou em baias de piso compacto, resulta em respostas de desempenho e de características de carcaças semelhantes. Entretanto, para a fase de crescimento, as baias com lâmina d'água proporcionam maior consumo de ração e ganho de peso, porém maior volume de dejetos é produzido.

Nenhum dos beirais analisados possui calhas de coleta de água. A falta de calha pode acarretar em contaminações do ambiente, uma vez que as águas precipitadas lavam o solo e conduzem matéria orgânica aos mananciais. A colocação de calhas de zinco ou plástico nos beirais dos telhados pode ser a solução mais eficiente para se evitarem contaminações. Seguindo recomendação técnica para cada tipo de calha (material), deverá haver a instalação de canos verticais de saída das mesmas, e ao encontrarem o solo subjacente, deverá haver canalização horizontal para conduzir as águas captadas pelas calhas para fora da área do sítio, sem que essas encontrem as canaletas de dejetos (BLEY JÚNIOR, 2003).

Notou-se que $60 \%$ dos beirais necessitam de algumas modificações, como aumentar a sua largura, para evitar a entrada de água nas instalações, e $40 \%$ estão adequados. Segundo a Resolução do SEMA nº 031/98 (IAP, 1998), os beirais devem ser construídos de forma que as águas das chuvas não caiam nas canaletas de coleta de dejetos.

Verificou-se que todas as canaletas são abertas, possibilitando a entrada da água da chuva; as canaletas externas de dejetos existentes deverão ser cobertas com placas de concreto com caixas de passagem, no mínimo, a cada $20 \mathrm{~m}$, podendo corresponder a distância das saídas de dejetos de cada baia, podendo ser aproveitadas as caixas de passagem existentes, as quais deverão ser mantidas tampadas permanentemente. Em alguns pontos das canaletas, a parte correspondente ao fundo deve passar por reforma. Nas canaletas internas de dejetos, deverá ser mantida uma lâmina d'água para definir a parte úmida das baias. Para isso, as canaletas deverão estar em nível, com saídas para as canaletas externas. Apesar de as lâminas d'água contribuírem para o conforto animal, gastam muita água, aumentando a produção de dejetos e a contaminação ambiental (BLEY JÚNIOR, 2003).

As caixas de passagem de dejetos até o local de depósito e tratamento, em $90 \%$ das instalações, precisam de algumas modificações, ou seja, possuem a passagem aberta, e em 10\% das instalações não possuem. Segundo a Resolução SEMA no 031/98 (IAP, 1998), as caixas de passagem devem ser fechadas e cobertas para evitar entrada de água das chuvas.

Quanto à realocação das instalações, observou-se que $10 \%$ das instalações precisam ser realocadas, pois estão em área de preservação permanente (APP) e $90 \%$ estão adequadas. Dos critérios locacionais, destacam-se os limites estabelecidos pelo Código Florestal Brasileiro, que é uma Lei Federal, cujos limites não podem ser flexionados, a qual, aplicada na Resolução SEMA no 031/98 (IAP, 1998), determina que a área do empreendimento, incluindo armazenagem, tratamento e disposição final de dejetos, deve situar-se a uma distância mínima de $30 \mathrm{~m}$ de corpos hídricos, de modo a não atingir áreas de preservação permanente.

De acordo com a Figura 4, 55\% das propriedades da microbacia do Córrego Ajuricaba não possuem a mata ciliar integral, conforme determina a Resolução SEMA $n^{\circ}$ 031/1998, que corresponde a $30 \mathrm{~m}$ de largura em cada margem do córrego. Somente $45 \%$ das propriedades possuem a mata ciliar composta. Porém, nenhuma delas está protegida, a maioria permite o acesso 
dos animais em seu interior, promovendo a compactação do solo e o escorrimento superficial, o que compromete a função da mata ciliar.

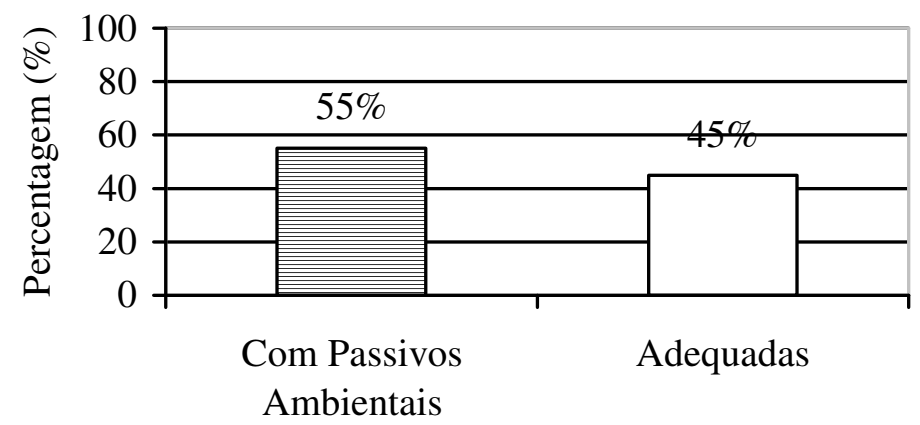

FIGURA 4. Percentagem de propriedades que estão com passivos ambientais e adequadas em relação à mata ciliar, na microbacia do Córrego Ajuricaba, no município de Marechal Cândido Rondon - PR.

Quanto ao isolamento das instalações das águas da chuva, todas precisam de readequação, devendo ser feita a construção de novos terraços e reforma dos já existentes, de maneira que interceptem a água, não a conduzindo para dentro das instalações. As águas de chuvas que se precipitam a montante dos sítios de produção deverão ser interceptadas e infiltradas no solo, mediante a construção de terraços de infiltração de maneira a não atingir a área dos sítios (BLEY JÚNIOR, 2003).

\section{CONCLUSÕES}

O perfil da suinocultura estudada corresponde a $80 \%$ de suinocultores com sistema de criação em terminação e $20 \%$ em ciclo completo. Essa proporção está relacionada ao modelo de criação integrada com grandes agroindústrias nesse setor, que segmentam a produção conforme a demanda industrial, a aptidão e o interesse de cada suinocultor.

A freqüência de limpeza das baias nas instalações é diária em $80 \%$ das unidades de produção de suínos, e as demais realizam a limpeza a cada dois ou mais dias. Os 80\% correspondem aos produtores integrados às agroindústrias, com produção em maior escala, cuja demanda por limpeza é diária.

O manejo da alimentação é adequado em todas as propriedades, não ocorrendo desperdício de ração, sendo os animais tratados três vezes ao dia, e os cochos são submetidos a manutenções periódicas.

Considerando as construções, o principal problema é o acesso das águas da chuva sobre as canaletas sem nenhum controle (falta de calhas), diluindo os dejetos e aumentando o seu volume, com isso encarecendo o transporte até às lavouras.

Todas as propriedades da microbacia do Córrego Ajuricaba possuem problemas com a mata ciliar, sendo que $55 \%$ necessitam de reposição florestal e $45 \%$ possuem mata ciliar integral.

\section{REFERÊNCIAS}

BLEY JÚNIOR, C.J. Projeto de controle da contaminação ambiental decorrente da suinocultura no Estado do Paraná. Curitiba: Ministério do Meio Ambiente, 2003. 162 p.

DOURMAD, J.Y.; GUINGAND, N.; LATIMIER, P.; SEVÉ, B. Nitrogen and phosphorus consumption, utilization and losses in pig production: France. Livestock Production Science, Shannon, v.58, p.199-211, 1999.

FERNANDES JÚNIOR, A. Tratamentos físicos e biológicos da manipueira. In: CEREDA, M.P. (Coord.) Manejo, uso e tratamento de subprodutos da industrialização da mandioca. São Paulo: Fundação Cargill, 2001. v.4, cap.10, p.138-50. 
IAP. Instituição Ambiental do Paraná. Resolução SEMA no 031 de 24 de agosto de 1998.

Legislação Ambiental. Disponível em: www.pr.gov.br/meioambiente/iap/res031.htm\#art96. Acesso em: 15 nov. 2005.

IBGE. Instituto Brasileiro de Geografia e Estatística. Censo Agropecuário 2003. Efetivo de suínos por região. Disponível em:

http://www.ibge.gov.br/home/estatistica/economia/agropecuaria/censoagro/brasil. Acesso em: 20 out. 2005.

ITAIPU BINACIONAL. Projeto cultivando água boa, apresentações de projetos. Disponível em: http://www.itaipu.gov.br/aguaboa/apresentacoes/caderno/Caderno \%20de\%20projetos_arquivos/fram e.htm. Acesso em: 22 nov. 2005.

JELINEK, T. Collection, storage and transport os swine wasters. In: TAIGANIDES, E.P. Animal wastes. Essex: England Applied Science, 1977. p.165-74.

KONZEN, E.A. Avaliação quantitativa e qualitativa dos dejetos de suínos em crescimento e terminação, manejados em forma liquida. 1980. 56 f. Dissertação (Mestrado) - Escola de Medicina Veterinária, Belo Horizonte, 1980.

MACKIE, R.I.; STROOT, P.G.; VAREL, V.H. Biochemical identification and biological origin of key odor in livestock waste. Journal of Animal Science, Savoy, v.76, p.1331-42, 1998.

MAMED, R.A. Consumo de água e relação água/ração para suínos em crescimento e terminação.1980. 23 f. Universidade Federal de Minas Gerais, Escola de Medicina Veterinária, Belo Horizonte, 1980.

MOREIRA, I.; PAIANO, D.; OLIVEIRA, G.C.; GONÇALVES, G.S.; NEVES, C.A. Performance and carcass traits of pigs (33-84 kg) reared on compact floor or with shallow pool. Revista Brasileira de Zootecnia, Viçosa, v.32, n.1, p.132-9, jan./fev. 2003.

OLIVEIRA, P.A.V. Manejo de água - influência do volume de dejetos produzidos. In: DIA DE CAMPO SOBRE MANEJO E UTILIZAÇÃO DE DEJETOS DE SUÍNOS, 1994, Concórdia. Anais... Concórdia: EMBRAPA/CNPSA, p.25-28.

OLIVEIRA, A.R. de Jr. Manejo de dejetos. 1994. Disponível em: www.conpassu.com.br/dejetos. Acesso em: 16 out. 2005.

SHARPLEY, A.; FOY, B.; WITHERS, P. Practical and annovative measures for the control of agricultural phosphorus losses to water: An overview. Journal of Environmental Quality, Madison, v.29, n.1, p.1-9, 2000.

SILVA, F.F.; FREITAS, P.S.L.; BERTONHA, A.; REZENDE, R.; GONÇALVES, A.C.A.; DALLACORT, R. Flutuações das características químicas do efluente industrial de fecularia de mandioca. Acta Scientiarum, Maringá, v.25, n.1, p.167-75, 2003.

VAN DER PEET-SCHWERING, C.M.C.; JONGBLOED, A.W.; AAMICK, A.J.A. Nitrogen and phosphorus consumption, utilization and losses in pig production: The Netherlands. Livestock Production Science, Netherlands, v.58, p.213-24, 1999.

VAVRA, M. Sustentainability of animal production systems: An ecological perspective. Journal of Animal Science, Savoy, v.74, p.1.414-23, 1996. 